\title{
Testing capturing methods for the Yellow-legged Tinamou Crypturellus noctivagus (Wied, 1820) (Aves, Tinamidae) in southern Brazil
}

\author{
Luiz Liberato Costa Corrêa ${ }^{1,2}$ \& Maria Virginia Petry ${ }^{1,3}$ \\ 1 Universidade do Vale do Rio dos Sinos (UNISINOS), Laboratório de Ornitologia e Animais Marinhos (LOAM). São Leopoldo, RS, Brasil. \\ 2 ORCID: 0000-0001-6543-3382. E-mail: Ic correa@yahoo.com.br (correspondence author) \\ 3 ORCID: 0000-0002-7870-7394. E-mail: vpetry@unisinos.br
}

\begin{abstract}
Specific and efficient methods for capturing tinamous are scarce in the scientific literature. Here we tested the effectivity of two methods for capturing the Yellow-legged Tinamou Crypturellus noctivagus (Tinamidae): a bell-trap adapted with a nylon cast net and a type of fall-trap. In a forest remnant in Rio Grande do Sul state, Brazil, we applied 120 hours of sampling effort using the traps, resulting in the capture of six individuals (two females and four males). These capture methods are an efficient tools and useful for forest tinamous studies, although it can be also used for capturing other forest bird which use the forest floor.
\end{abstract}

Key-Words. Tinamiformes; Bell-trap; Neotropical Forest.

\section{INTRODUCTION}

Tinamous are terrestrial birds endemic to the neotropical region, and found both in forests and open environments (Sick, 1997). They are inconspicuous and difficult to visualize in forest due to their plumage patterns, but they are usually recorded by vocalization (Cabot, 1992). Because of continuous habitat fragmentation and predatory hunting, some species of this group are considered threatened (Cabot, 1992; Garnero et al., 2006). Due the secretive habits of the species, most biological information on this group are known only by casual observations (Höhn, 1975; Schelsky, 2004; Brennan, 2009). The lack of described field methodologies for tinamous studies, when compared to other bird groups, and the almost absence of efficient methods for capturing these species are challenges to research projects. Specific techniques focused in capturing and handling tinamous in the field are still poorly available in the scientific literature and usually lack detailed descriptions of species-specific adaptions for different environments. Despite the difficulties, Piratelli (2003), Brennan (2004), Ghizoni-Jr. \& Graipel (2005), Garnero et al. (2006), Freitas et al. (2013), Garitano-Zavala et al. (2013) and Silva et al. (2013) described procedures that resulted in successfully capture of tinamous in their natural habitats.

The Yellow-legged Tinamou Crypturellus noctivagus (Wied, 1820) is an endemic species from Brazil which occurs mainly in forests within the
Atlantic Forest and Pampa biomes, and is currently considered threatened of extinction at the national level (Sick \& Teixeira, 1979; Piacentini \& Straube, 2008; Tomotani \& Silveira, 2016). In the Rio Grande do Sul state, the species is considered as critically endangered (FZB, 2014) and only one relictual population is known to occur recently in the state. Future studies in this region are needed to better understand the species population patterns, such as structure and dynamics of this regional population (Corrêa et al., 2010).

In this study we tested the efficiency and the procedures of two alternative methods for capturing C. noctivagus. Successful capture methods may allow sampling of biological material for future studies about population genetics and other biological issues, thus contributing to the conservation strategies for this threatened species.

\section{MATERIAL AND METHODS}

This study was conducted in a 450 ha forest remnant between São Sepé and Formigueiro $\left(30^{\circ} 05^{\prime} 35,3^{\prime \prime} \mathrm{S}, 53^{\circ} 36^{\prime} 22,9^{\prime \prime} \mathrm{W}\right)$ (Fig. 1), Rio Grande do Sul state, Brazil. The study site is isolated from other forest remnants in the region, and is surrounded by rural areas where cattle raising, rice and soy farming activities predominate (Corrêa et al., 2010). This region belongs to the Pampa biome and presents deciduous seasonal forests (IBGE, 2004). 
We concentrated the capture efforts between October and December 2015, during spring and summer seasons, the breeding period of the tinamous in southern Brazil (Belton, 1994; Sick, 1997). Two capturing methods for $C$. noctivagus were used during five consecutive days, totaling eight hours of effort per day, starting at 7 a.m. We used three bell-traps, following Bub (1991), although adapted with nylon cast nets (1.5 mm mesh). The cast nets had about 10 meters of circumference and $1.80 \mathrm{~m}$ of diameter (Fig. 2A). We used a plastic malleable hose as an arc attached in the opening, forming a circle, in order to keep the net open. The second method consisted in the use of three pyramid fall-traps, also adapted. The pyramid fall-traps measured $70 \times 40 \times 40 \mathrm{~cm}$ and were constructed in a rectangular form, using $6 \mathrm{~mm}$ diameter iron bars arranged as the frame and a black plastic mesh fixed with plastic cable ties as the covering (Fig. 2B). A wooden rod was used as the trigger. Additionally, we placed a ceramic replica of a $C$. noctivagus specimen on the ground near the bell-traps to attract the birds (Fig. 2C). Belltraps were set up about 1.5-2 $\mathrm{m}$ from the ground, fixed in branches in the treetops, stretched with nylon, translucent and strong lines. Three wooden stakes $(40 \mathrm{~cm}$ length) were used, fixed on the ground, to tie the nylon line which lifts the bell-traps from the ground (Fig. 2D). We also used playback at each two minutes to attract the birds (Dabelsteen \& Pedersen, 1991; Bibby et al., 1992). As soon as a C. noctivagus individual responded to playback we recorded its vocalization using a digital recorder and reproduced the playback once again. As the bird approached and entered the trap the researcher, wearing camouflage clothes, manually dropped the line thus releasing the trap over the bird.

The bell-shaped nets were placed in random spots within the forest fragment, mainly along trails or in glades near the fragment border. The bell-traps were disposed in two ways: (1) linearly, in positions that allow a good view of the birds, following this order: the first was placed about five meters from the researcher, the second about 10 meters, and the third about 15 meters from the researcher, or (2) triangularly, where two bell-traps were placed about five meters from the researcher (and from each other) and the third about 15 meters from the researcher (Fig. 3). When the linear method was not efficient in capturing the attracted individual (after $\sim 5$ hours of capturing effort), we interrupt the use of playback for about one hour, in order to induce the bird to leave the site. Then, we changed the traps organization from linearly to triangular, or vice versa. In both methods (linear and triangular), we also placed a pyramid fall-trap from about two meters of distance to each bell-trap, using $200 \mathrm{~g}$ of shredded corn and rice grains as baits.
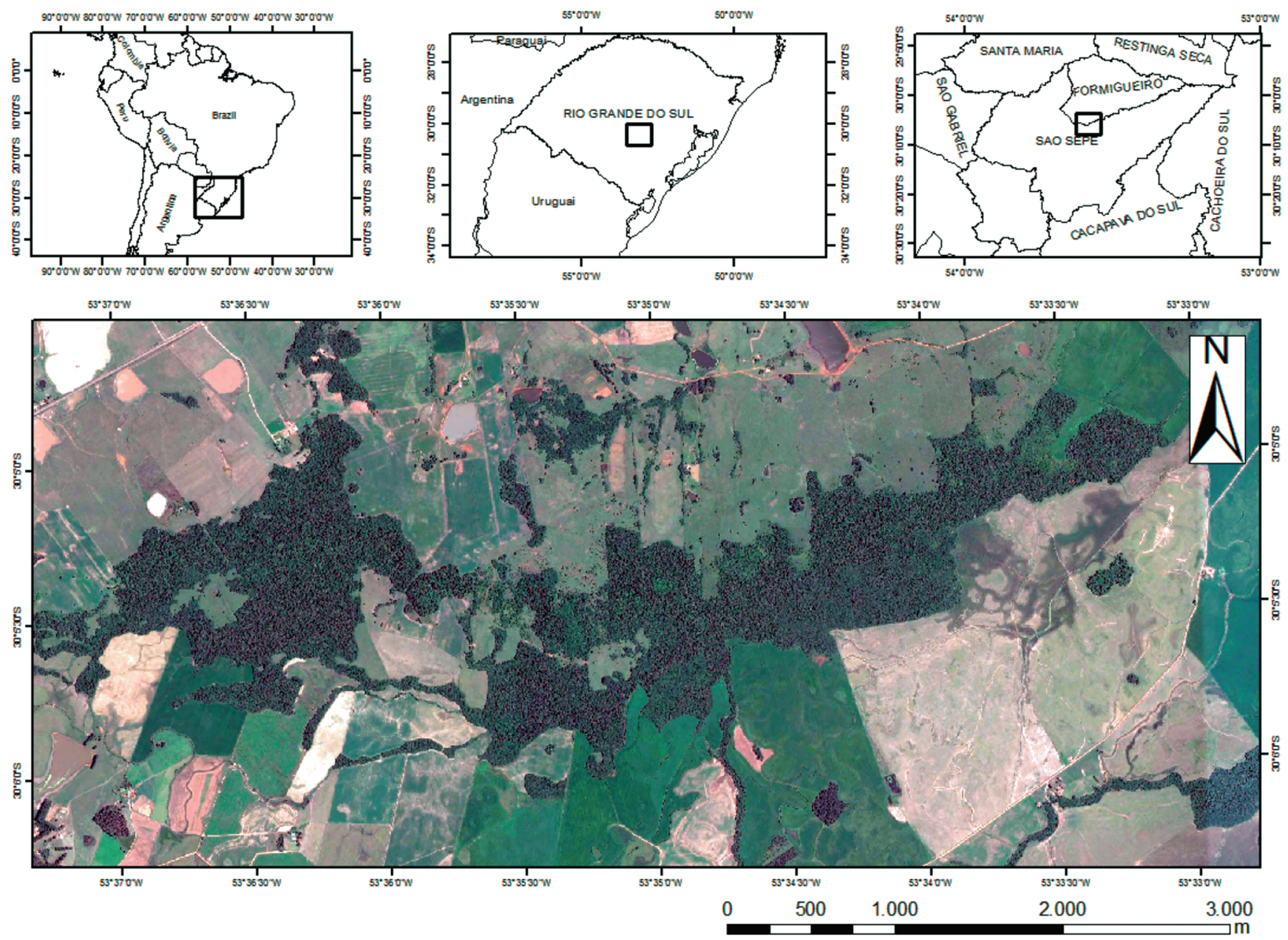

Figure 1. Study area, located between São Sepé e Formigueiro, Rio Grande do Sul state, Brazil. 

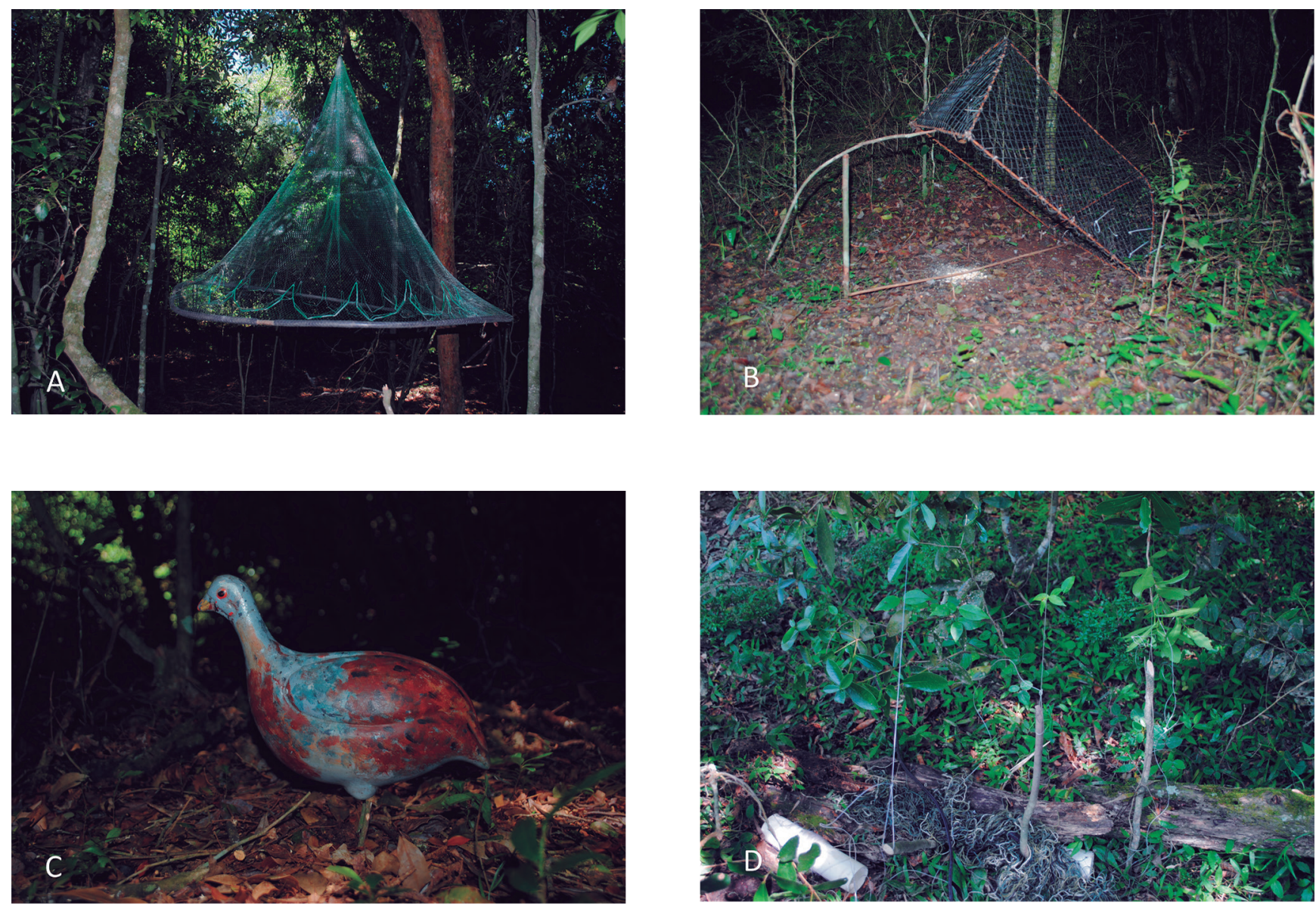

Figure 2. Bell-trap: (A) Plastic hose keeping the trap open. (B) Pyramid fall-trap with automatic trigger and cereal baits. (C) Tinamou ceramic replica. (D) Wooden stakes fixed on the ground, holding the nylon line which lifts the bell-trap.

After being captured, individuals were marked with metal bird rings provided by the National Center of Research and Conservation of Wild Birds (CEMAVE). As this species does not present apparent sexual dimor-

(A)

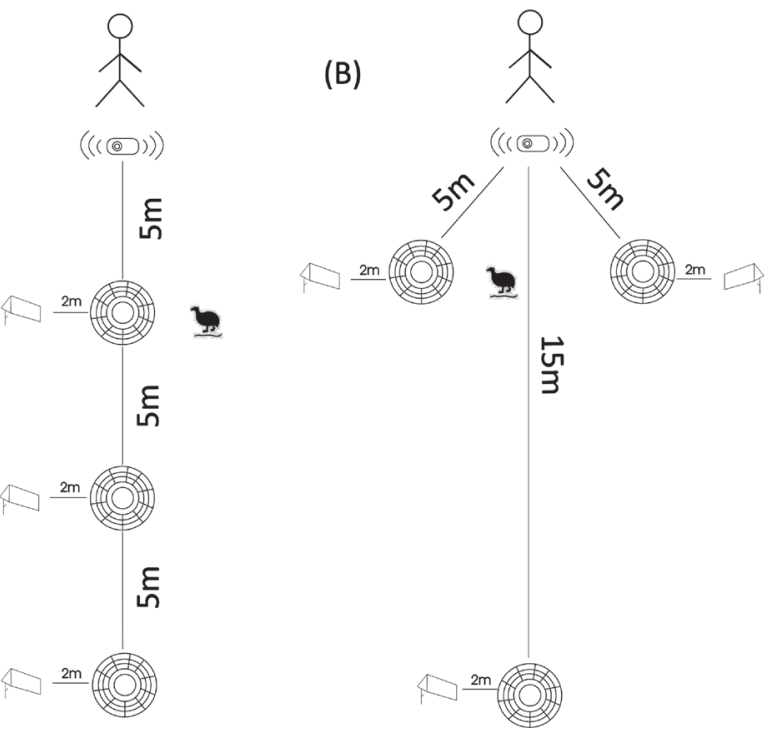

Figure 3. Illustrative scheme of the capturing procedures. (A) Linear arrangement of the bell-traps. (B) Triangular arrangement of the bell-traps. Arrangement of the tinamous replica and pyramid fall-traps. phism (Magalhães, 1994), we collected blood samples to molecular sexing.

\section{RESULTS AND DISCUSSION}

After 120 hours of sampling effort using bell-traps we captured six individuals of Crypturellus noctivagus (two females and four males). Only one individual escaped before the bell-trap reached the ground, resulting in $85.7 \%$ of success. The linear way for traps arrangement resulted in four captures, while the triangular way resulted in the capture of only two individuals. Thus, for each 20 hours of sampling effort, we were able to capture one individual of $C$. noctivagus. The use of playback technique along with the tinamous replica seemed to be indispensable for capture the birds. Captured individuals did not present agitation, and most of them stayed static while tangled in the cast net. However, two individuals presented death-feigning behavior during nets removal, a similar behavior described by Brennan (2004) for the Great Tinamou (Tinamus major). One individual of C. noctivagus escaped during the beginning of sampling activities probably because we released the bell-trap before the bird reached completely the exact range of the trap. Thus, we recommend researchers to delimitate the range of the trap on the ground, for example by using wooden 
sticks, in order to choose right moment to manually release the bell-traps.

We believe the use of pyramid fall-traps was not efficient in this study mostly because of the baits we used did not included the natural food of the birds. We recommend the use of natural food items as baits, such as fruits and seeds collected on the ground in the study area. Other kinds of baits were reported in the literature for tinamous capture using ground traps. Ghizoni-Jr. \& Graipel (2005) reported the capture of Crypturellus obsoletus using peanut butter and bananas, while Freitas et al. (2013) reported the capture of C. tataupa and C. parvirostris using a mix composed by peanut butter, soy oil, corn meal and bacon. Brennan (2004) used crushed corn grains for capturing T. major.

Considering the difficulties in applying methods for capturing forest tinamous, which may require intense sampling effort and a variety of field adaptations according to the local conditions, the method used in this study, associated with the use of tinamous replicas and playback, presented a considerable efficiency in sampling. We hope that this capturing method may be used for other forest-dwelling tinamous. This method is inexpensive and requires only two researchers in the field and it may be adapted to capture other forest bird species which use the ground for displacement and foraging.

\section{ACKNOWLEDGMENTS}

We would like to thank the study area owners for allowing us to access the area. To colleagues from the Laboratório de Ornitologia e Animais Marinhos (UNISINOS) for field work support. To Coordenação de Aperfeiçoamento Pessoal de Nível Superior (CAPES) for the scholarship. To Diogo Tobolski for the elaboration of the study area map. The capture techniques were both approved by System of Authorization and Information of Biodiversity (SISBIO, № 47126-3) by the Ethics Committee on the Use of Animals in Research (CEUA, № PPECEUAI0.2014), Universidade do Vale do Rio dos Sinos.

\section{REFERENCES}

Belton, W. 1994. Aves do Rio Grande do Sul: distribuição e biologia. São Leopoldo, Editora Unisinos.

Bibby, C.; Jones, M. \& Marsden, S. 1992. Expedition field techniques: bird surveys. Cambridge, BirdLife International.

Brennan, P.L.R. 2004. Techniques for studying the behavioral ecology of forest - Dwelling Tinamous (Tinamidae). Ornitologia Neotropical, 15: 1-9.

Brennan, P.L.R. 2009. Incubation in great tinamous (Tinamus major). Wilson Journal of Ornithology, 121(3): 506-511.

Bub, H. 1991. Bird Trapping and Bird Banding: A handbook for Trapping methods all over the world. New York, Cornell University Press.
Cabot, J. 1992. Order Tinamiformes. In: Del Hoyo, J.; Elliot, A. \& Sargatal, J. (Eds.). Handbook of the birds of the world. Barcelona, Lynx Editions. p. 112-125.

Corrêa, L.L.C.; Silva, D.E. \& Cappellari, L.H. 2010. Aves, Tinamidae, Crypturellus noctivagus noctivagus (Wied, 1820): southward range extension and rediscovery in Rio Grande do Sul, Brazil. ChekList, 6(4): 485-486.

Dabelsteen, T. \& Pedersen, S.B. 1991. A portable digital sound emitter for interactive playback of animal vocalisations. The International Journal of Animal Sound and its Recording, 3(3): 193-206.

Freitas, M.A.; Miranda, T.F.; França, D.P.F.; Abraão, J.; Oliveira, L.; Silva, D.C.; Araújo, D.; Estavilho, C.; Aves, R.; Hamdan, B.; Nunes, 0.C.; Carvalho, M.; Coelho, D.P.; Abreu, R.O. \& Silva, T.F.S. 2013. Registros de capturas acidentais de aves e répteis em armadilhas para mamíferos no estado da Bahia, Brasil. Atualidades Ornitológicas, 175: 33-39.

FZB - Fundação Zoobotânica do Rio Grande do Sul. 2014. Espécies da Fauna Silvestre Ameaçadas de Extinção no Estado do Rio Grande do Sul. Decreto № 51.797, de 08 de Setembro de 2014. Available at: www.al.rs.gov. br/filerepository/repLegis/arquivos/DEC\%2051.797.pdf. Access in: 10/01/2017.

Garitano-Zavala, A.; Chura, Z.; Cotín, J.; Ferrer, X. \& Nadal, J. 2013. Home range extension and overlap of the Ornate Tinamou (Nothoprocta ornata) in an Andean agro-ecosystem. The Wilson Journal of Ornithology, 125(3): 491-501.

Garnero, A. Del, V.; Ledesma, M.A. \& Gunski, R.J. 2006. Alta homeologia cariotípica na família Tinamidae (Aves: Tinamiformes). Revista Brasileira de Ornitologia, 14(1): 53-58.

Ghizoni-Jr., I.R. \& Graipel, M.E. 2005. Capturas acidentais de vertebrados em estudos com pequenos mamíferos no estado de Santa Catarina, sul do Brasil. Biotemas, 18(1): 163-180.

Höhn, E.0. 1975. Notes on Black-headed Ducks, Painted Sinipe, and Spotted Tinamous. Auk, 92: 566-575.

IBGE - Instituto Brasileiro de Geografia e Estatística. 2004. Mapa de Vegetação e Biomas do Brasil, Escala: 1:5.000.000. Available at: https://ww2.ibge. gov.br/home/presidencia/noticias/21052004biomashtml.shtm. Access in: 12/01/2017.

Magalhães, J.C.R. 1994. Sobre alguns tinamídeos florestais brasileiros. Boletim Centro de Estudos Ornitológicos, 10: 16-24.

Piacentini, V.Q. \& Straube, F.C. 2008. Crypturellus noctivagus noctivagus (Wied, 1820). In: Machado, A.B.M.; Drummond, G.M. \& Plagia, A.P. (Eds.). Livro Vermelho da Fauna Brasileira ameaçada de Extinção. Brasília, DF: MMA; Belo Horizonte, MG: Fundação Biodiversitas. p. 384-385.

Piratelli, A. 2003. Mesh size and bird capture rates in Mato Grosso do Sul state, Brazil. Brazilian Journal of Biology, 63(1): 105-111.

Schelsky, W.M. 2004. Research and conservation of forest-dependent tinamou species in Amazonia Peru. Ornitologia Neotropical, 15: 317-321.

Sick, H. 1997. Ornitologia Brasileira. Rio de Janeiro, Nova Fronteira.

Sick, H. \& Teixeira, D.M. 1979. Notas sobre aves brasileiras raras e ameaçadas de extinção. Publicações Avulsas Museu Nacional, 62: 1-39.

Silva, V.B.C.; Freitas, F.L.C. \& Momo, C. 2013. Aspectos morfológicos do proventrículo e ventrículo gástrico de Crypturellus parvirostris (Wagler, 1827). Ciência Animal Brasileira, 14(1): 106-112.

Tomotani, B.M. \& Silveira, L.F. 2016. A reassessment of the taxonomy of Crypturellus noctivagus (Wied, 1820). Revista Brasileira de Ornitologia, 24(1): 34-45. 